\title{
PENGEMBANGAN E-MODUL WRITING FOR PROFESSIONAL CONTEXT BERSTANDAR CEFR BERDASARKAN KARAKTERISTIK PEKALONGAN KOTA KREATIF DUNIA
}

\author{
Inayatul Ulya, M. Fajru Sidqi \\ Pendidikan Bahasa Inggris \\ Fakultas Keguruan dan Ilmu Pendidikan \\ Universitas Pekalongan \\ Korespondensi: inayasetyobudi@yahoo.com
}

\begin{abstract}
The development of technology demanded the teaching material to be designed digitally. This study was aimed to develop CEFR (Common European Framework)-standard Writing for Professional Context teaching material in the form of Pekalongan the world creative city e-module. Research and development $(R \& D)$ was used in conducting this research. Observasion sheet, questionnaire and interview were used to collect the data. The results showed that E-Model of Writing for professional context was needed by the students. Therefore, the researcher did a plan of developing an e-module. After it was designed, it was validated by the validators for getting the suggestion of the betterment. Finishing the validation process, next the e-module of Writing for Professional Context standardized by CEFR with the characteristic of Pekalongan the World Creative city was revised and published. The title of the e-modul is Let's Write: Pekalongan the World Creative City. The texts types in this e-modul were written with their social functions, generic structure and linguistic. The content of the texts described Pekalongan as the World Creative City.
\end{abstract}

Keywords: CEFR, e-module, writing, creative

\section{PENDAHULUAN}

Keberlangsungan proses belajar mengajar meliputi beberapa komponen, baik berupa perangkat pembelajaran, media pembelajaran, bahan ajar dan evaluasi. Menurut Laila dkk (2019: 1) pembelajaran merupakan komponen isi pesan dalam kurikulum yang harus disampaikan kepada siswa. Seiring dengan perkembangan teknologi, proses belajar mengajar perlu dikembangkan dengan pemanfaatan teknologi. Pembelajaran tidak hanya diselenggarakan di kelas berupa tatap muka, namun dapat dilakukan dengan blended learning atau bahkan e-learning. Untuk mendukung proses pembelajarn tersebut, tentunya bahan ajar sangat dibutuhkan. Menurut Yezita, dkk (2012: 55), bahan ajar adalah segala benuk bahan yang digunakan untuk membantu guru/instruktur dalam melaksanakan kegiatan pembelajaran di kelas yang disusun secara sistematis baik tertulis maupun tidak tertulis. Melihat kondisi sekarang ini di mana mahasiswa lebih menyukai mengakses informasi melalui gawai dibanding dengan membaca buku cetak, maka bahan ajar yang disiapkan perlu dikembangkan sesuai dengan kebutuhan mahasiswa.

Bahan ajar dapat berupa buku ajar, buku teks, diktat, handout, lembar kerja siswa, dan modul. Dengan berkembangnya teknologi, modul dapat berupa modul elektronik (Emodule). Modul elektronik merupakan bahan ajar yang disusun berdasarkan kurikulum yang diterapkan, berisi materi dan latihan-latihan yang dapat diakses secara daring sehingga peserta didik dapat melakukan belajar mandiri.. Sebagaimana dikemukakan oleh Purwaningtyas (2017: 121), modul elektronik merupakan bentuk bahan ajar yang sesuai dengan karakteristik materi ajar yang telah dikemas dalam satu kesatuan yang utuh, yang disusun secara sistematis dipelajari secara mandiri dan lebih aktif oleh pembelajar sesuai dengan kecepatan atau kemampuannya tanpa bimbingan dari guru. Selain itu, Kementerian Pendidikan dan Kebudayaan (2017: 3) 
menytakan bahwa E-modul merupakan sebuah bentuk penyajian bahan belajar mandiri yang disusun secara sistematis ke dalam unit pembelajaran tertentu, yang disajikan dalam format elektronik, di mana setiap kegiatan pembelajaran di dalamnya dihubungkan dengan tautan (link) sebagai navigasi yang membuat peserta didik menjadi lebih interaktif dengan program, dilengkapi dengan penyajian video tutorial, animasi dan audio untuk memperkaya pengalaman belajar. Pengembangan bahan ajar hendaknya memperhatikan prinsip-prinsip bahan ajar berikut: (1) mulai dari yang mudah untuk memahami yang sulit, dari yang kongkret untuk memahami yang abstrak; (2) pengulangan memperkuat pemahaman; (3) umpan balik positif memberikan penguatan terhadap pemahaman siswa; (4) motivasi yang tinggi merupakan salah satu faktor penentu keberhasilan belajar; (5) mencapai tujuan; dan (6) mengetahui hasil yang dicapai (Depdiknas, 2008: 11).

Sebelum melakukan pengembang pada bahan ajar, peneliti menganalisis kebutuhan pengembangan bahan bahan ajar pada program studi Bahasa Inggris Fakultas Keguruan dan Ilmu Pendidikan Univeristas Pekalongan, khususnya pada mata kuliah Writing for Professional Context. Mata kuliah tersebut didesain agar mahasiswa mampu menuliskan text types sesuai dengan social function, generic structure dan linguistic features. Menulis merupakan kegiatan yang dilakukan untuk menuangkan ide-ide dalam bentuk informasi tertulis yang dapat dipahami oleh pembaca. Menurut Meyer (2005: 3), menulis merupakan kegiatan seperti berbicara kepada orang lain yang dilakukan pada lembaran kertas atau layar komputer. Konten materi pada mata kuliah Writing for Professional Context berupa text types. Text types merupakan kumpulan teks yang mempuyai karakter yang khas pada tiap teks, baik dari fungsi sosial, struktur teks, dan ciri kebahasaan. Menurut Anderson M. dan Anderson K (2003: 1), ada dua kategori utama teks, yaitu teks sastra dan teks faktual. Di dalamnya ada berbagai jenis teks. Setiap jenis teks memiliki ciri kebahasaan. Teks sastra meliputi narrative, poetry, dan drama, sedangkan faktual teks meliputi recount, explanation, discussion, information report, , exposition, procedure, response. Pada proses pembelajaran yang telah berlangsung pada Program Studi Pendidikan Bahasa Inggris (PBI) Universitas Pekalongan, mahasiswa memakai buku pegangan berupa buku teks. Konten dari buku ini lebih menyajikan pada budaya-budaya yang tidak menggambarkan kearifan lokal yang ada di lingkungan mahasiswa. Untuk mengetahui apakah kearifan lokal dapat dijadikan pijakan dalam menyusun bahan ajar, peneliti merujuk pada penelitian-penelitian yang telah dilakukan oleh peneliti sebelumnya.

Maryati (2019) melakukan penelitian dengan judul Pengembangan E-Modul Android APPYET Berbasis Kearifan Lokal Lampung pada Mata Pelajaran Biologi untuk Peserta Didik Kelas X di Tingkat SMA. Pembelajaran Biologi di SMA kelas $\mathrm{X}$ bahan ajar yang digunakan dalam pembelajaran ekositem berupa buku teks yang disediakan dari sekolah namun belum adanya bahan ajar berbasis kebudayaan. Pentingnya kesadaran kebudayaan harus ditanamkan dan tentunya melalui jalur pendidikan. Pendidikan berbasis kebudayaan adalah alat paling ampuh dalam rangka menanamkan kesadaran berbudaya dengan karakter jati diri sesungguhnya dan melestarikan nilai-nilai kearifan lokal. Pengembangan mencakup tiga hal pokok, yaitu desain, materi dan bahasa. Dalam penelitian ini bertujuan untuk: 1) mengetahui pengembangan e-modul biologi berbasis aplikasi android Appyet materi ekosistem lokal Lampung untuk peserta didik kelas $\mathrm{X}$; 2) Untuk mengetahui kelayakan pengembangan e-modul biologi berbasis aplikasi android Appyet materi ekosistem lokal Lampung untuk peserta didik kelas X. Penelitian ini merupakan jenis penelitian Research and Development (R\&D) yang menggunakan prosedur Borg \& Gall. Dalam penelitian ini terdapat penilaian ahli media, ahli bahasa, ahli materi, peserta didik dan guru biologi. Penelitian ini dilakukan di tiga sekolah di Bandar Lampung, pengumpulan data dilakukan dengan menggunakan kuisioner/angket, wawancara dan dokumentasi. Berdasarkan penelitian ini, diperoleh produk dengan penilaian ahli media sebesar 91,34\%; ahli materi sebesar $84,72 \%$; ahli bahasa sebesar 
$100 \%$ dengan kriteria kelayakan "Sangat Layak". Kemudian produk diuji coba melalui 2 tahap yaitu uji coba skala terbatas dan uji coba lebih luas. Uji coba skala terbatas mendapatkan hasil 76,83\%, selanjutnya uji coba lebih luas di dua sekolah yang berbeda mendapatkan hasil $78,40 \%$ dan $78,37 \%$. Hasil tanggapan pendidik sebesar 75,69\%，80,55\% dan 70,83\%. Berdasarkan hasil penelitian ini dapat disimpulkan bahwa e-modul biologi berbasis aplikasi android Appyet materi ekosistem lokal Lampung sangat layak untuk dimanfaatkan dalam pembelajaran SMA di Bandar Lampung

Nurrahmi (2018) melakukan penelitian dengan judul Pengembangan Modul Berbasis Kearifan Lokal Daerah Istimewa Yogyakarta Tema Pendidikan untuk Siswi Kelas III Sekolah Dasar. Tujuan dari penelitian ini untuk menghasilkan produk berupa modul berbasis kearifan lokal Daerah Istimewa Yogyakarta tema pendidikan yang layak untuk siswa kelas III SD. Penelitian ini merupakan penelitian dan pengembangan yang didasarkan pada pengembangan R\&D dari Thiagarajan, Semmel $\&$ Semmel yang disebut dengan model Four-D. Namun, desain pengembangan modul ini hanya meliputi tiga langkah yang terdiri dari define, design, dan develop. Hasil penilaian ahli bahwa modul tersebut telah layak diujicobakan dengan dibuktikan dari hasil validasi ahli materi dan ahli media. Hasil validasi ahli media mendapat skor rata-rata 3,60 dengan kategori baik. Hasil validasi ahli materi mendapat skor rata-rata 4,18 dengan kategori baik. Hasil angket respon guru mendapat skor rata-rata 4,5 dengan kategori sangat baik. Hasil uji coba perorangan mendapat skor rata-rata 4,39 dengan kategori sangat baik. Hasil uji coba kelompok kecil mendapat skor rata-rata 4,57 dengan kategori sangat baik. Hasil uji coba lapangan mendapat skor rata-rata 4,56 dengan kategori sangat baik

Menelaah pada penelitian terdahulu, peneliti melakukan analisis kebutuhan pengembangan e-modul dengan konten yang dikaitkan dengan kearifan lokal Kota Pekalongan, dengan asumsi bahwa penggunaan konten kearifan lokal dapat memupuk rasa cinta peserta didik terhadap budaya yang terdapat di daerahnya. Penelitian yang telah dilakukan oleh tim memiliki kesamaan dalam hal desain pada penelitian yang dilakukan oleh Maryati (2019), peneliti menggunakan desain pengembangan emodul dan kearifan lokal daerah. Namun terdapat perbedaan dalam hal mata pelajaran, yaitu biologi dan writing (menulis). Kearifan lokal juga berbeda daerah, yaitu Lampung dan Kota Pekalongan.

Selain itu, penelitian yang telah dilakukan oleh tim memiliki kesamaan dalam hal desain penelitian yang dilakukan oleh Nurrahmi (2017), peneliti menggunakan desain pengembangan berupa modul dan kearifan lokal daerah. Namun terdapat perbedaan, pada penelitian ini dilakukan pengembangan $e$-modul (elektronik modul). Selain itu, terdapat perbedaan pada topik modul, yaitu modul kearifan lokal tema pendidikan dan writing (menulis). Kearifan lokal yang dijadikan dasar dalam menyusun bahan ajar juga berbeda daerah, yaitu Yogyakarta dan Kota Pekalongan

Kearifan lokal dapat dijadikan landasan dalam mengembangkan bahan ajar. Rahyono (2015) mendefinisikan kearifan lokal sebagai kecerdasan yang dihasilkan berdasarkan pengalaman yang dialami sendiri dan dijadikan milik bersama. Pengalaman yang dialami sendiri ini merupakan pengalaman yang dirasakan seseorang dalam suatu masyarakat dan berlangsung terus menerus sehingga menjadi suatu kebudayaan. Selain itu, Mufid (2010: 84) menyatakan bahwa kearifan lokal merupakan salah satu produk kebudayaan ataupun sumber pengetahuan masyarakat yang muncul karena kebutuhan nilai, norma, dan aturan yang menjadi model untuk bertindak. Mufid juga menjelaskan bahwa kearifan lokal terdapat pada tradisi, sejarah, pendidikan, seni, agama dan lainnya.

Mengingat Universitas Pekalongan berlokasi di Kota Pekalongan, maka mahasiswa perlu dikenalkan dengan lingkungan belajar bahwa Pekalongan dikukuhkan sebagai The World Creative City oleh UNESCO. Sebagaimana dikemukakan oleh Royani (2017) Kota Pekalongan secara resmi ditetapkan sebagai anggota jejaring kota kreatif UNESCO pada 1 Desember 2014. Kota Pekalongan menjadi kota pertama di Indonesia bahkan di Asia Tenggara yang masuk dalam jejaring kota 
kreatif. Kota Pekalongan masuk dalam jaringan kota kreatif dalam kategori craft and folk.

Dalam pengembangan bahan ajar, dibutuhkan standard. Salah satu standard tersebut yaitu Common European Framework (CEFR). CEFR merupakan standard yang diakui secara internasional untuk menggambarkan kecakapan berbahasa. Sebagaimana dinyatakan oleh Council of Europe (2001: 1), Common European Framework (CEFR) memberikan deskripsi umum untuk elaborasi silabus bahasa, pedoman kurikulum, evaluasi, bahan ajar di Eropa. CEFR menjelaskan secara komprehensif apa yang harus dipelajari oleh pembelajar bahasa untuk menggunakan bahasa untuk berkomunikasi dan pengetahuan serta keterampilan apa yang harus mereka kembangkan agar dapat bertindak secara efektif. Deskripsi tersebut mencakup konteks budaya di mana bahasa diatur. CEFR menetapkan tingkat kemahiran bahasa dalam enam tingkat, A1 hingga $\mathrm{C} 2$, yang dapat dikelompokkan kembali menjadi tiga tingkat besar: pengguna dasar (basic user), pengguna independen (independent user), dan pengguna mahir (proficient user), dan dapat dibagi lagi sesuai dengan kebutuhan konteks lokal. Tingkatannya dilakukan melalui deskriptor "mempu melakukan".
Dengan latar belakang tersebut, dapat disimpulkan bahwa tujuan dari penelitian ini yaitu mengembangkan E-Modul Writing for Professional Context berstandar CEFR (Common European Framework) berdasarkan karakteristik Pekalongan kota kreatif dunia.

\section{METODE PENELITIAN}

Penelitian ini merupakan penelitian dan pengembangan (Research and Development). Menurut Sugiyono (2016: 30), penelitian pengembangan ( $R$ \& D) dapat diartikan sebagai cara ilmiah untuk meneliti, merancang, memproduksi, dan menguji validitas produk yang telah dihasilkan. Sebagaimana Borg and Gall (1983) mendefinisikan pendekatan penelitian dan pengembangan as "a process used to develop and validate educational product". Proses ini berarti merujuk pada analisis kebutuhan, dan hasil analisis digunakan dalam pengembangan sebuah produk. Selain itu, validator memilki peranan penting untuk memvalidasi hasil penelitian. Dengan demikian langkah yang digunakan meliputi:

a) Tahap analisis(research and collecting information)

b) Tahap pengembangan(Developing form of product)

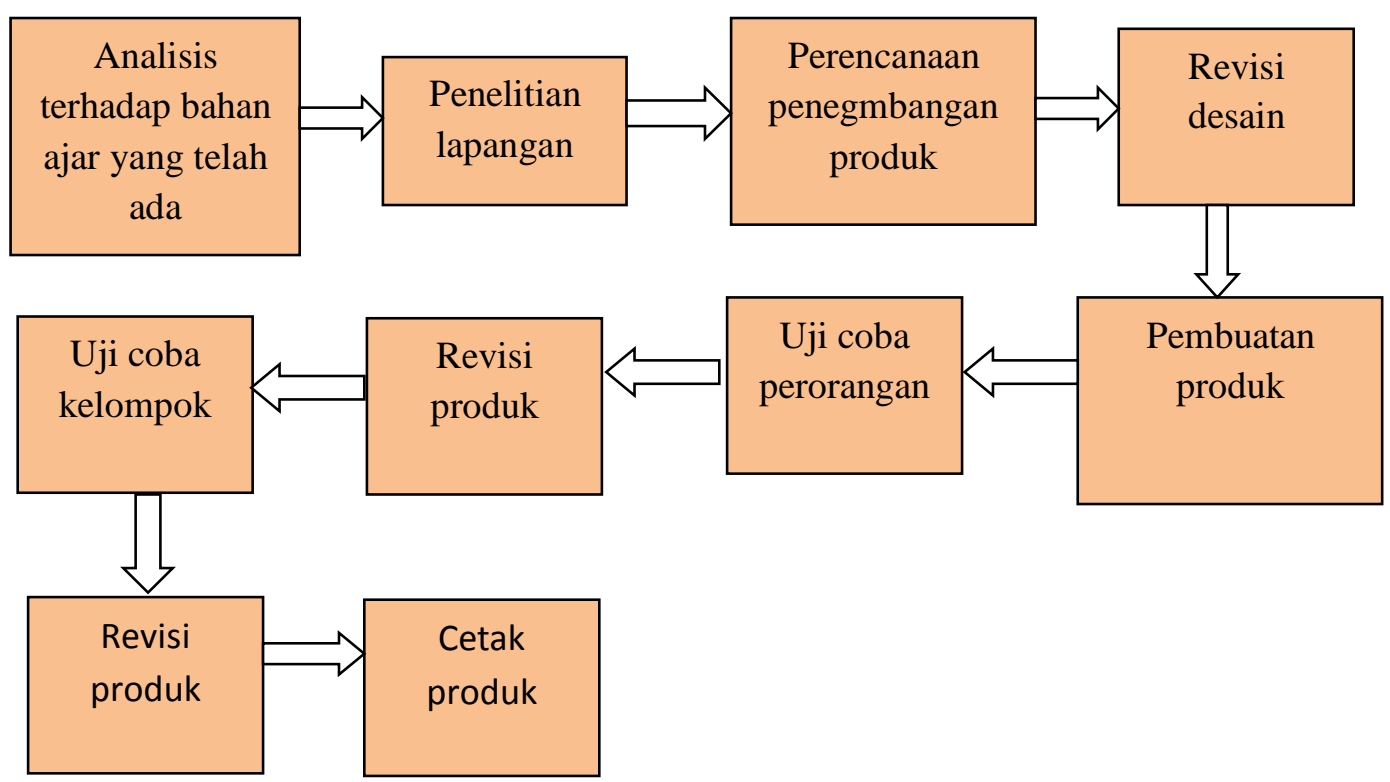

Gambar 1 Bagan Prosedur Penelitian Research and Development 
Teknik pengumpulan data menggunakan dua lapis dalam penelitian dan pengembangan; teknik pengumpulan data untuk analisis kebutuhan, dan teknik pengumpulan data untuk pengembangan produk (Borg \& Gall: 1983). Ada beberapa cara yang digunakan dalam teknik instrumentasi ini yaitu; observasi dan analisis hasil observasi, wawancara, dan angket.

\section{HASIL DAN PEMBAHASAN}

Mahasiswa program studi Pendidikan Bahasa Inggris Universitas Pekalongan memerlukan pembelajaran adaptif sebagai respon kemajuan teknologi. Kebutuhan modul dalam Writing for Professional Context diperlukan agar memiliki gambaran instruksional pembelajaran dari awal hingga akhir. Instruksi aktivitas pembelajaran dan bahan ajar disusun dengan jelas.

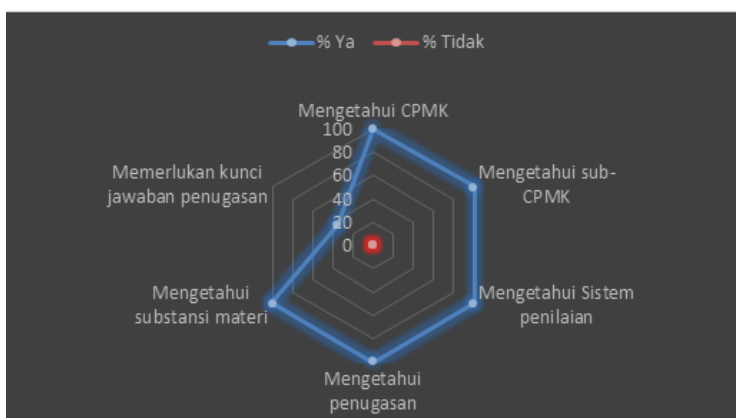

Gambar 2 Diagram Kebutuhan Bahan ajar E-Modul

Angket kebutuhan E-modul memuat pertanyaan terbuka menukik pada pertanyaan kebutuhan bahan ajar dalam bentuk modul elektronik (E-modul). Semua pernyataan tentang E-modul ditanggapi secara positif oleh mahasiswa. Modul elektronik memberikan kemudahan bagi mahasiswa dikarenakan secara instruksional jelas dan dapat dibuka di mana saja. Aspek kepraktisan juga menjadi pertimbangan karena akses materi dapat dibuka kapan saja. Selain itu dengan adanya e-modul, menjadikan ramah lingkungan karena mengurangi penggunaan kertas.

Pengembangan bahan ajar berbentuk $e$ modul diputuskan setelah melalui proses analisis kebutuhan, studi literatur dan pengamatan lapangan. Langkah berikutnya dalam mengembangkan modul adalah perencanaan pengembangan produk, pembuatan produk, uji coba perorangan, revisi produk, dan produksi hasil akhir.

\subsection{Perencanaan}

Tahapan ini berupa tindakan pasca analisis kebutuhan, rangkaian hasil angket dan observasi dikompilasi dan dicatat rekomendasirekomendasi berkaitan dengan kerangka materi Writing for Professional Context. Rekomendasi dari hasil analisis kebutuhan meliputi: a) penetapan standar CEFR (Common European Framework References on Language pada mata kuliah Writing for Professional Context; b) penetapan Rencana Pembelajaran Semester (RPS) dan Rancangan Tugas (RT) yang adaptif terhadap konteks karakteristik kearifan local; c) melakukan identitifikasi materi ajar teks yang sesuai dengan karakteristik Kota Pekalongan sebagai kota kreatif dunia; d) menyusun materi teks dan penugasan dengan standar CEFR, e) menyusun sistematika modul berbentuk elektronik.

\subsubsection{Penetapan standar CEFR}

Standar CEFR diputuskan setelah melalui masukan dari para pihak pemangku kepentingan internal prodi Pendidikan Bahasa Inggris (PBI) Universitas Pekalongan. Sebagaimana disinggung sebelumnya, CEFR terdiri dari enam (6) level dari A1, A2, B1, B2, $\mathrm{C} 1, \mathrm{C} 2$ dengan berbagai kriteria penguasaan capaian.

\subsubsection{Penetapan Rencana Pembelajaran Semester(RPS) dan Rancangan Tugas (RT)}

Sebagai bahan dasar penyusunan e-modul Writing for Professional Context, wajib didasarkan dari Rencana Pembelajaran Semester (RPS). Deskripsi mata kuliah menjadi kunci pengembangan RPS terutama dalam penulisan CPMK (Capaian Pembelajaran Mata Kuliah). CPMK dibagi menjadi dua jenis kompetensi: kompetensi kognitif dan kompetensi psikomotor, pada ranah psikomotor, mahasiswa diharapkan mampu menganalisis, mengevaluasi, dan mencipta ragam teks Bahasa Inggris berjenis teks monolog berdasar nalar kritisisime ilmiah secara andragogis.

Sedangkan pada ranah psikomotor, mahasiswa diharapkan mampu menyusun dan menyaji baik secara abstrak dan konkret ragam 
teks Bahasa Inggris berjenis teks monolog berdasar nalar kritisisme secara andragogis. Penetapan RPS dan RT melibatkan tim dosen mata kuliah keahlian Bahasa Inggris di semua bidang keahlian, hal ini penting dilakukan agar tuntas dalam penyusunan tingkatan pemahaman kognitif dan psikomotor.

\subsubsection{Identitifikasi materi ajar teks}

Proses identifikasi memperhatikan aspek Pekalongan kota kreatif dunia dengan analisis keterkaitan antara indikator kota kreatif dengan judul teks yang akan dipilih. Identifikasi dilakukan mencari sejumlah sepuluh (10) judul teks

Tabel 1 Relevansi Teks dengan Pekalongan Kota Kreatif

\begin{tabular}{|c|c|c|c|}
\hline No. & Jenis teks & Judul Teks & Indikator Kota Kreatif \\
\hline 1 & Recount Text & Celebrating Syawalan Tradition & Dasar kreatif \& tradisi kota \\
\hline 2 & Narrative Text & History of Pekalongan & Sejarah kota \\
\hline 3 & Report Text & Batiks & Industri kreatif \\
\hline 4 & Descriptive Text & $\begin{array}{l}\text { My Tranformative Creative campus- } \\
\text { UNIKAL }\end{array}$ & $\begin{array}{l}\text { Ketersediaan institusi } \\
\text { pendidikan tinggi }\end{array}$ \\
\hline 5 & Procedure Text & How to Make Tauto & Dinamika budaya \& kuliner \\
\hline 6 & $\begin{array}{l}\text { Explanation } \\
\text { Text }\end{array}$ & $\begin{array}{l}\text { Why Pekalongan called as the World } \\
\text { Creative City }\end{array}$ & Peran kota kreatif \\
\hline 7 & News Item Text & $\begin{array}{l}\text { Nusantara Batik Week Conserved Local } \\
\text { Wisdom }\end{array}$ & $\begin{array}{l}\text { Festival seni budaya skala } \\
\text { besar }\end{array}$ \\
\hline 8 & $\begin{array}{l}\text { Analytical } \\
\text { Exposition }\end{array}$ & Drop out students should be prevented & Peran professional \& LSM \\
\hline 9 & $\begin{array}{l}\text { Hortatory } \\
\text { Exposition }\end{array}$ & $\begin{array}{l}\text { Environment Awareness should be } \\
\text { Improved }\end{array}$ & $\begin{array}{l}\text { Pendidikan masyarakat kota } \\
\text { kreatif }\end{array}$ \\
\hline 10 & Discussion Text & Pros and Cons of Tiban Market & $\begin{array}{l}\text { Ekonomi \& dinamika } \\
\text { budaya }\end{array}$ \\
\hline
\end{tabular}

Judul teks yang dipilih memiliki keterkaitan erat dengan indikator kota kreatif dunia yang ditentukan oleh UNESCO. Kesepuluh judul teks ini memenuhi indikator meskipun tidak semua tercantum. Kontekstualisasi teks lazim dilaksanakan dosen maupun institusi pendidikan dalam rangka memperkenalkan budaya dan karakteristik masyarakat, dan teks yang disajikan mengandung nilai universal. Sifat teks yang disajikan teks panjang memuat informasi tersurat dan tersirat dan meningkatkan nalar kritis mahasiswa sehingga secara andragogis membuat mereka berpikir analitis dalam membaca isi teks.

\subsubsection{Menyusun materi dan penugasan}

Penyusunan materi memperhatikan indikator Pekalongan sebagai kota kreatif dunia, dikemas dalam isu yang kontemporer menjadi gagasan dalam teks. Unsur-unsur text-type seperti struktur generik, fungsi sosial, dan unsur kebahasaan disisipkan sesuai dengan jenis teksnya. Variasi bahasa disusun untuk memberikan motivasi kepada mahasiswa dalam memahami isi teks, dan dipadukan dengan kontekstualitas materi teks.

Bentuk modul pasti berbeda dengan isi buku, sifatnya yang sangat instruktif memberi kemudahan mahasiswa menyerap materi dengan cepat. Materi yang disusun harus pula disertakan bentuk penugasan.

\subsubsection{Penyusunan sistematika e-modul}

Sebagai bahan ajar, modul elektronik harus memiliki tingkat keterbacaan yang mudah dipahami oleh mahasiswa, baik diinstruksi, materi, maupun penugasan. Sistematika disusun dengan memperhatikan kelaziman modul secara teoretik maupun konvensi yang berlaku di CEFR.

\subsection{Pembuatan Produk}

Tahapan ini menuntut kecermatan karena menghubungkan mata kuliah Writing for Professional Context dengan standar CEFR dan unsur kontekstualisasi Pekalongan sebagai kota kreatif dunia. Pembuatan produk e-modul dilakukan dengan beberapa langkah 


\subsubsection{Sinkronisasi}

Data yang didapatkan pada tahapan perencanaan disaling-silang-masukkan ke dalam sistematika e-modul. Sub CPMK disinkronkan dengan tujuan pembelajaran, narasi teks dilakukan proses editing dan penyisipan gambar, hingga tugas-tugas yang disinkronkan dengan teori tentang fungsi sosial, struktur teks, dan unsur kebahasaan. Semua kesepuluh jenis text type mengalami proses sinkronisasi menjadi kesatuan data pada $e$ modul.

\subsubsection{Penggabungan teks - teks antar unit}

Tujuan penggabungan antar teks ini agar tercipta ketersambungan dan kesamaan isu tentang Pekalongan kota kreatif dunia. Modul disusun terdiri dari sembilan (9) bagian agar sesuai dengan RPS. Pada dasarnya e-modul ini merupakan pengembangan RPS agar secara instruksional materi dapat terserap secara cepat oleh mahasiswa.

\section{Cover}

2. Halaman cover

3. Preface

4. Table of content

5. How to use this module

6. Unit 1. Recount

7. Unit 2 Narrative

8. Unit 3. Report

9. Unit 4. Descriptive

10. Unit 5. Procedure Text

11. Unit 6. Explanation

12. Unit 7. Analytical Exposition

13. Unit 8. Hortatory Exposition

14. Unit 9. News Item

15. Unit 10. Discussion

16. References

17. Appendix

\section{Gambar 3 Sistematika Susunan Modul}

\subsection{Uji Coba dan Validasi}

Kegiatan validasi dilaksanakan di kelas semester 2 prodi PBI UNIKAL, mata kuliah Writing for Professional Context, dengan jumlah mahasiswa sebanyak 36. Uji coba perorangan dilakukan terbatas menggunakan model stratified sampling, sampel terdiri dari 3 kelompok mahasiswa dengan kemampuan tinggi, kemampuan sedang, dan kemampuan rendah, masing-masing kelompok terdiri dari dua (2) mahasiswa.

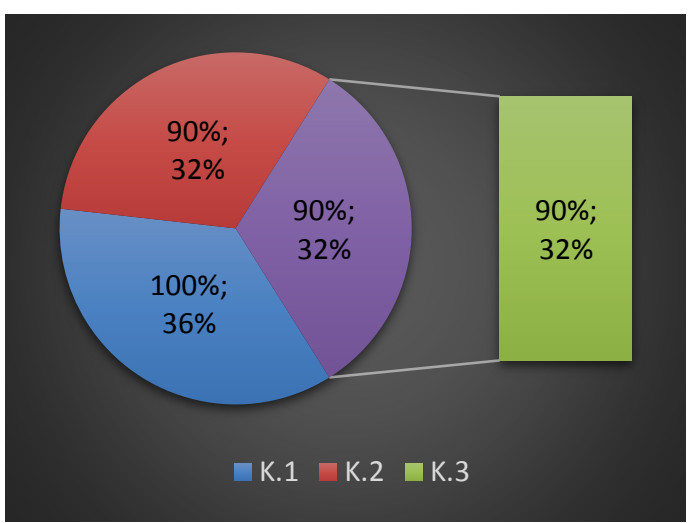

Gambar 4 Diagram persepsi e-modul

Pelaksanaan uji coba ini diimbangi dengan proses validasi oleh validator yang ahli pada bidangnya, dari komponen-komponen pertanyaan dapat dihasilkan data sebagai berikut:

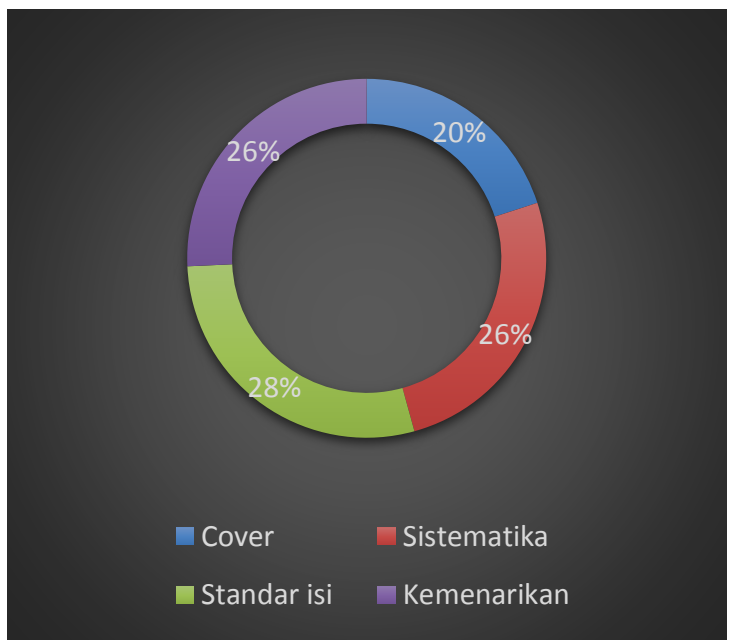

Gambar 5 Diagram persepsi validator e-Modul

Persepsi validator mencakup empat (4) hal, yaitu cover, sistematika, standar isi, dan kemenarikan penyajian. Cover menjadi aspek penting karena menjadi pembeda antara modul dan buku. Validator memberikan catatan minor pada desain dengan tulisan text types cenderung teoretik daripada praktik yang bersifat instruksional. 
Catatan minor berikutnya ada pada sistematika, jadi pada bagian sistematika penulisan perlu membuat instruksi-instruksi materi dan penugasan dengan menggunakan bahasa yang ringan dan semi-formal. Catatan mayor didapatkan pada isi dari materi e-modul, penggunaan standar CEFR dan isi teks sudah tepat dengan kriteria-kriterianya.

\subsection{Revisi dan hasil akhir produk e modul}

Tahahap revisi dilaksanakan dengan memperhatikan hasil persepsi mahasiswa dan persepsi validator. Secara keseluruhan memuat komponen penyajian cover, komponen isi yaitu materi teks, materi teori, dan materi penugasan, komponen sistematika yaitu langkah-langkah instruksional tentang e-modul mata kuliah Writing for Professional Context. Catatan mayor dan minor seoptimal mungkin diperbaiki agar dapat diterima oleh mahasiswa. Hasil akhir dari revisi akan berbentuk modul elektronik yang diunggah pada wesite FKIP UNIKAL.

\subsubsection{Revisi sajian cover}

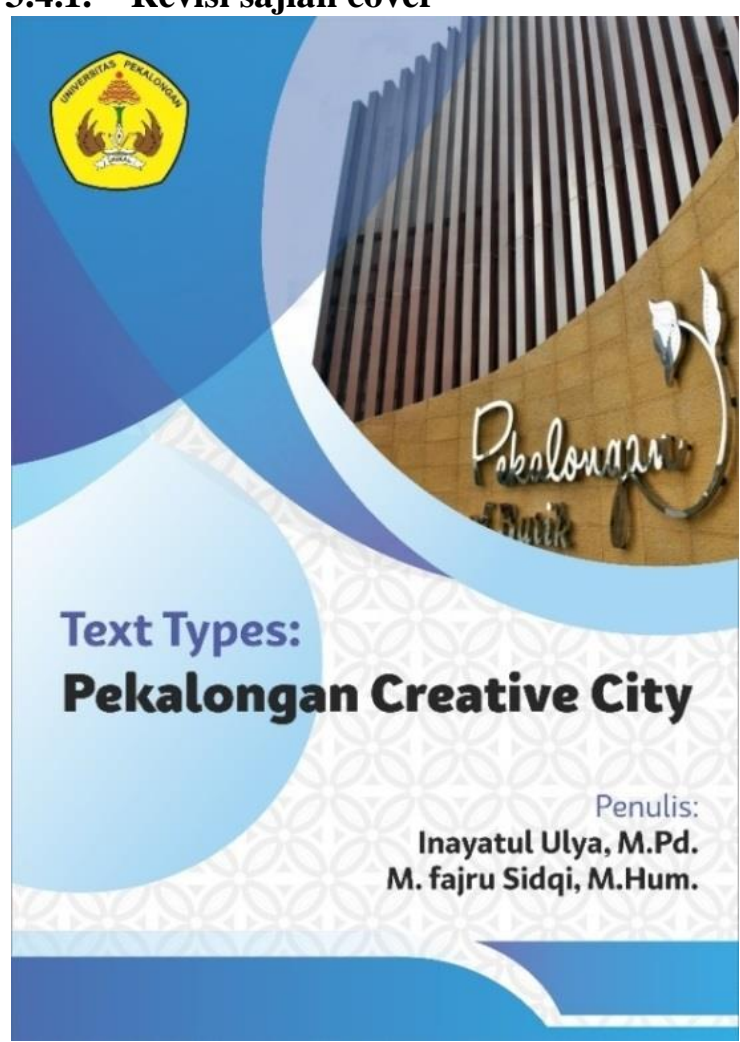

Gambar 6 Cover Awal Sebelum Validasi

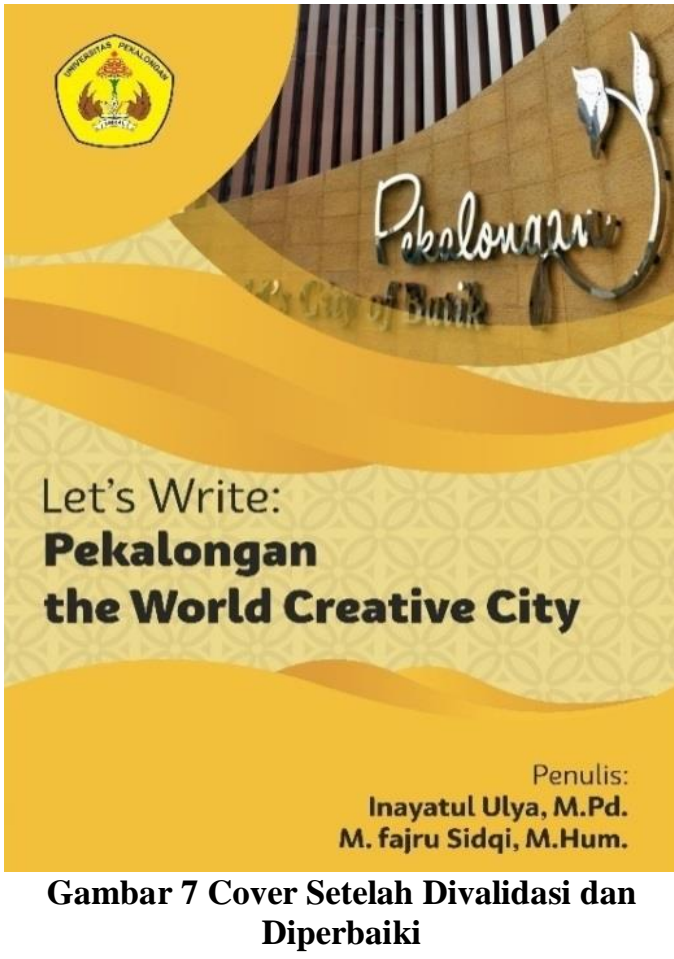

Sajian cover dalam persepsi validator adalah adanya pembeda dengan buku, secara persuasif mengajak pembaca untuk menyelami makna judul modul tersebut. Pilihan kata kunci yang direkomendasikan adalah penggunaan kata Let's Write: Pekalongan the World Creative City. Kata let's write lebih semi formal dan fleksibel terhadap persepsi membaca mahasiswa. Materi text types adalah materi serius yang lebih menyenangkan jika disajikan dengan santai dan menggunakan ragam sajian populer.

\subsubsection{Revisi sistematika dan langkah} instruksional

Sistematika dan langkah instruksional juga harus fleksibel walaupun merujuk pada RPS dan RT. Kedua dokumen ini sifatnya formal sebagai standar bagi FKIP UNIKAL dalam memastikan ketercapaian profil lulusan yang baik. Penyusunan modul adalah perangkat bantu untuk mempermudah proses belajar mengajar. Kemudahan dilihat dari penulisan sistematika dan langkah instruksional. Sistematika mewakili kesan awal mahasiswa dalam membaca materi Writing for Professional Context, sementara instruksional mewakili kemudahan aktivitas mahasiswa dalam mengikuti pembelajaran. 
Saran ditujukan agar pembelajaran berbasis digital menjadi efektif bagi Prodi PBI UNIKAL:

a) KKNI sebagai patron utama kurikulum perlu distandarkan penyusunannya dari level universitas hingga program studi.

b) Prodi PBI perlu dengan segera menyusun standarisasi kelompok mata kuliah keahlian dengan CEFR sebagai kerangka dasar penyusunan kurikulum prodi.

c) Mahasiswa tetap berpegang pada buku teks utama jika ada materi yang terdapat pada $e$ modul memerlukan pendalaman.

d) Buku teks yang dimaksud harus direkomendasikan dan dicantumkan pada $e$ modul Writing for Professional Context sebagai bahan belajar mahasiswa.

\section{DAFTAR PUSTAKA}

Anderson, M. \& Anderson, K. 2003. Text Types in English. South Yarra. MacMillan Education Australia.

Borg \& Gall. 1983. Educational research and development. New York :Mc Gill Education.

Council of Europe. 2001. Common European Framework of References for Languages: Learning, teaching, assessment.

Depdiknas. 2008. Teknik Penyusunan Modul. Jakarta: Direktorat Jendral Manajemen Pendidikan Dasar dan Menengah.

Kementerian Pendidikan dan Kebudayaan Republik Indonesia. 2017. Pedoman Pengembangan Materi Pembalajaran Jakarta.

Laila, R. dkk. 2019. Pengembangan Bahan Ajar Fisika: Pengertian, Jenis-Jenis dan Karakeristik Bahan Ajar Cetak Meliputi Handout, Modul, Buku (Diktat, Buku Ajar, Buku Teks), LKS, Pamflet. Universitas Negeri Padang. Padang.

Maryati, M. 2019. Pengembangan E-Modul Android Appyet Berbasis Kearifan Lokal Lampung Pada Mata PelajaranBiologiUntukPesertaDidikKel as X SMA. Skripsi . UIN RadenIntan. Lampung. Diakses dari http://repository.radenintan.ac.id/6560/
Meyers, Alan. 2005. Gateways to Academic Writing. New York. Pearson Education, Inc.

Mufid, A. S. 2010. Revitalisasi Kearifan Lokal dalam Pemberdayaan Masyarakat. Harmoni - Jurnal Multikultural \& Multireligius Vol. IX No. 34 halaman 83-92. UIN SunanKalijaga. Yogyakarta

Nurrahmi, R.2018. Pengembangan Modul Berbasis Kearifan Lokal Daerah Istimewa Yogyakarta Untuk Siswa Kelas III Sekolah Dasar. Jurnal EdukasiVol III. UNY. Yogyakarta. Diakses dari http://journal.student.uny.ac.id/ojs/inde x.php/pgsd/article/view/11033

Purwaningtyas, Dwiyogo, W.D., Hariyadi, I. (2017). Pengembangan Modul Elektronik Mata Pelajaran Pendidikan Jasmani, Olahraga, dan Kesehatan Kelas XI Berbasis Online dengan Program Edmodo. Jurnal Pendidikan: Teori, Penelitian, dan Pengembangan, Vol: 2 Nomor: 1. Halaman 121-129. Diakses dari http://journal.um.ac.id/index.php/jptpp/ article/view/8471.

Rahyono.2015. Peranan Kearifan Lokal dalam Pendidikan Karakter. Diakses dari journal.uinjkt.ac.id. UNJ Press. Jakarta

Royani M, Ulfah. 2017. Latar Belakang UNESCO Menetapkan Pekalongan sebagai Jejaring Kota Kreatif Tahun 2014. UPN Veteran Yogyakarta.

Sugiyono. 2016. Metode Penelitian \& Pengembangan (Research and Developmet). Bandung. Alfabeta.

www.cefr.eu

Yezita, E. Media R., Yerizon. (2012). Mengkonstruksi Pengetahuan Siswa pada Materi Segitiga dan Segiempat Menggunakan Bahan Ajar Interaktif Matematika Berbasis Konstruktivisme. Jurnal Pendidikan Matematika. Vol. 1 No. 1. Hal 54-59. Diakses dari https://drive.google.com/file/d/0Bk3cSUkM3IyY2VLODM3a1h3aEU/vie $\underline{\mathrm{w}}$. 